\section{Aseemista okkultismia: Austin Osman Sparen maagiset monogrammit}

\author{
Riikka Ala-Hakula
}

Austin Osman Spare (1886-1956) oli englantilainen okkultisti ja kuvataiteilija, jonka järjestelmään kuului uudenlainen maagisten monogrammien ${ }^{1}$ luomisen tekniikka. Itse hän käytti näistä maagisista kuviosta useimmiten sanaa sigil ja tavoitteli niiden avulla erilaisia henkisiä ja fyysisiä voimia. Hänelle monogrammit olivat myös esteettisesti merkittäviä, sillä hän liitti niitä osaksi kuvataidettaan. Sparen roolit okkultistina ja kuvataiteilijana kietoutuvat yhteen ja vaikuttivat erottamattomalla tavalla toisiinsa hänen teoksissaan. Spare otti vaikutteita antiikista ja keskiajalta ${ }^{2}$ juontuvasta maagisten merkkien perinteestä, joka kuului kuvamagian ja rituaalimagian aloihin ${ }^{3}$. Se levisi renessanssin aikana $\mathrm{H}$. Cornelius Agrippan (1486-1535/1536) ja
Giordano Brunon (1548-1600) kaltaisten kirjoittajien vaikutuksesta, jotka laativat systemaattisia esityksiä maagisten merkkien käytöstä. Sittemmin 1600- ja 1700-luvuilla muun muassa varhaisen teosofin Jakob Böhmen (1575-1624) kirjoitukset ja ruusuristiläinen symboliikka välittivät niihin liittyvää esoteerista ajattelua. Tultaessa 1800- ja 1900-lukujen vaihteen Lontooseen uudet okkultistiset ${ }^{4}$ liikkeet, kuten Hermetic Order of the Golden Dawn, loivat omia historiallisesta perinteestä ammentaneita maagisia merkkejä hyödyntäneitä tekniikoita. Myöhemmin 1970-luvulla Sparen maagiset monogrammit puolestaan vaikuttivat kaaosmagiaa ${ }^{5}$ käsittelevien tekstien kautta populaarikulttuuriin samaan tapaan kuin häntä tunnetumman Aleister Cro- wleyn (1875-1947) uskonto Thelema ja siinä käytetty rituaalimagia.

Käsittelen tässä artikkelissa Sparen monogrammin luomisen tekniikkaa aseemisuuden näkökulmasta. Käsite on otettu käyttöön 1990-luvun puolivälissä visuaalisten runoilijoiden Jim Leftwichin ja Tim Gazen aloitteesta runouden kentällä ${ }^{6}$. Aseeminen kirjoitus näyttää kirjoitukselta, mutta sitä ei voi lukea luonnollisten kielten ${ }^{7}$ tavoin, koska

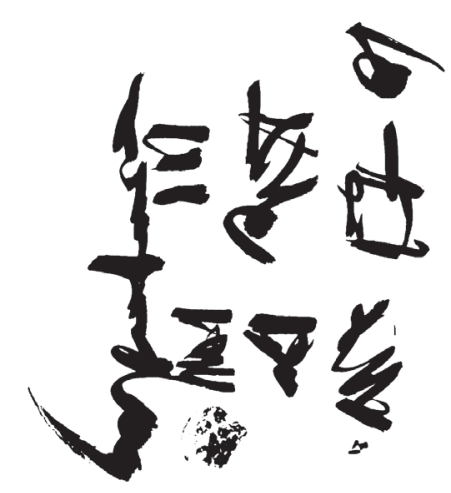

Kuva 1. Tim Gazen aseemista kirjoitusta. Lehdestä Asemic Magazine 3. Saatavissa: https://www.scribd.com/document/82862141/asemic-magazine-3. Luettu 8.10.2018. 
se ei välitä niille tyypillisiä konventionaalisia merkityksiä (ks. Kuva 1). Aseeminen kirjoitus välittää visuaalisia merkityksiä, joiden tulkintaan vaikuttaa visuaalinen perinne, johon analyysin kohteena oleva aineisto kytkeytyy. Aseemiseksi tulkittavaa kirjoitusta on tehty pitkään runouden, kuvataiteen ja okkultismin piirissä. Akateemisessa tutkimuksessa käsitettä on käytetty silloin, kun termi kuvaa parhaiten käsiteltävää aineistoa ${ }^{8}$ Nina Parishin mukaan Tim Gazen kaltaisten nykyrunoilijoiden ja kuvataiteilijoiden kiinnostukseen luoda aseemista kirjoitusta ovat vaikuttaneet Henri Michaux (1899-1984) ja Christian Dotremont (1922-1979) ${ }^{9}$. He molemmat tutkivat runouden ja kuvataiteen väliin sijoittuvaa aluetta ja loivat kirjoitusta, joka ei välittänyt konventionaalisia merkityksiä ${ }^{10}$. He ovat kuitenkin vain kapea esimerkki aseemisen kirjoituksen tradition laajuudesta. Tässä artikkelissa kartoitetaan aseemisen kirjoituksen aineistoja maagisten merkkien perinteestä.

Spare painottaa teoksessaan The Book of Pleasure (Self-Love): The Psychology of Ecstasy (1913), että monogrammia luotaessa pyritään siihen, ettei se sisällä visuaalista yhteyttä magian harjoittajan lauseeksi muotoilemaan tahtoon ${ }^{11}$. Tämä tarkoittaa sitä, että Sparen järjestelmässä maagisen merkin luomisen prosessissa tavoitteena on muokata luettava teksti aseemiseksi. Länsimaisen esoterian perinteessä on salakirjoituksien ja maagisten merkkien avulla haluttu tarkoituksella kätkeä kirjoituksen sanoma ja estää sen välittyminen kaikille. Tämän perinteen tarkastelu aseemisen kirjoituksen näkökulmasta kiinnittää huomion maagisten merkkien luettavuuden eri tasoihin. Tästä syystä myös sellaisten aineistojen tarkastelu on mielekästä, jossa maagiset merkit eivät ole täysin aseemisia. Kirjoitan artikkelin alussa Sparen rooleista okkultistina ja kuvataiteilijana, jonka jälkeen käsittelen hänen tekniikkaansa luoda maaginen monogrammi. Seuraavaksi sijoitan Sparen monogrammit osaksi maagisten merkkien historiaa. Lopuksi kokoan yhteen esimerkkejä siitä, millaisin tavoin maagisten merkkien lukemista vaikeutetaan ja niistä tehdään aseemisia.

\section{Spare okkultistina ja kuvataiteilijana 1900-luvun alun Lontoossa}

Spare omistautui kuvataiteelle jo teini-ikäisenä, jolloin Royal College of Art myönsi hänelle stipendin ja opiskelupaikan ${ }^{12}$. Hänen teoksensa hyväksyttiin Lontoon Royal Academyn näyttelyyn näiden opintojen aikana ja hän nousi julkisuuteen nuorena taitelijalupauksena ${ }^{13}$. Ensimmäisen kokoelman piirroksia ja aforismeja Spare julkaisi 18-vuotiaana kirjassa Earth Inferno (1905). Phil Baker on verrannut Sparen tyyliä symbolisti Aubrey Beardsleyn ${ }^{14}$ (1872-1898) eroottisiin töihin ja renessansssimaalari Albrecht Dürerin ${ }^{15}$ (1471-1528) muotokuviin. Vuonna 1911 Observer-lehden taidekriitikko vertasi Sparea William Blakeen $(1757-1827)^{16}$. Erityisesti hänen lahjakkuuttaan muotokuvien tekijänä ja okkultististen aiheiden kuvaajana symbolismin keinoin arvostettiin. Sparen työskentely kuvataiteilijana kytkeytyi hänen okkultistisiin menetelmiinsä, sillä hän liitti piirroksiinsa usein itämaisista uskonnoista ammentavaa symboliikkaa ja maagisia merkkejä. Hänen tunnetuimpien töidensä joukkoon kuuluvat omakuva Portrait of the Artist (1907) sekä okkultistista symboliikkaa sisältävä The Death Posture (1913)17. Uransa alun menestyksen jälkeen Spare otti etäisyyttä taidemaailmaan ja siellä saavuttamaansa maineeseen kirjalla The Anathema of Zos: 
The Sermon to the Hypocrites (1927), joka sisälsi rivien välissä arvostelua kuraattoreita, kriitikoita ja muita taiteilijoita koh$\operatorname{taan}^{18}$. Tämän jälkeen hän menetti keskeiset kontaktinsa taidekenttään, minkä takia hän on jäänyt taidehistoriassa vähemmän tunnetuksi. Spare tunnetaankin paremmin okkultismin kuin kuvataiteen piirissä.

Eri uskonnoista ja länsimaisen magian perinteestä otetut vaikutteet olivat tyypillisiä Lontoossa 1800- ja 1900-luvun vaihteessa vaikuttaneille esoterian suuntauksille, kuten Helena Blavatskyn (18311891) tunnetuksi tekemälle teosofialle. Spare tunsi Blavatskyn teoksia ja ammensi niistä Idän uskonnoista lainattuja tekniikoita $^{19}$. Sparen maaginen monogrammi oli mahdollista aktivoida myös meditaation tai mantran avulla ${ }^{20}$. Tämän lisäksi hänen symbolijärjestelmänsä elementit Zos ja Kia sisältävät kaikuja saksalaisen mystikon Jakob Böhmen ajattelusta ${ }^{21}$, jonka tekstit edustivat vanhempaa teosofiaa ja vaikuttivat ruusuristiläiseen ajatteluun ${ }^{22}$. Muita Lontoossa vaikuttaneita liikkeitä olivat Ordo Templi Orientis ja Hermetic Order of the Golden Dawn. Ordo Templi Orientis käytti itämaisista uskonnoista peräisin olevia vaikutteita, kuten hindulaista tantraa, luoden omia seksimagian tekniikoita ${ }^{23}$. Hermetic Order of the Golden Dawn -järjestön piirissä oli puolestaan kehitetty oma maagisen karakterin luomisen tekniikka ${ }^{24}$.

Sparen järjestelmä liittyi näihin suuntauksiin, koska sen elementtien Zos ja Kia symboliikka oli seksuaalista ja hänen keskeinen tekniikkansa oli maagisen merkin luominen. Spare kuului hetken Crowleyn hallinnoimaan järjestöön Argenteum Astrum (myös muodossa $A_{:}$. A:, suom. "Hopeinen Tähti") ${ }^{25}$. Crowley oli puolestaan osallistunut ajan okkultististen liikkeiden toimintaan, sillä hän johti Ordo Templi Orientis -järjestön Lontoon osastoa ja hän oli edennyt pitkälle Hermetic Order of the Golden Dawnin järjestelmässä ${ }^{26}$. Crowleyn ja Sparen järjestelmille yhteistä oli se, että ne muodostivat oman esoteerisen symboliikan, joka perustui itse luotuun mytologiaan. He molemmat myös ammensivat symboliikkaa ja tekniikoita eri maiden uskonnoista ja länsimaisen magian perinteestä. Crowleyn uskonto sisälsi elementtejä egyptiläisestä mytologiasta ${ }^{27}$. William Wallace puolestaan on tulkinnut Sparen symbolijärjestelmän elementtien sisältävän yhteyksiä kabbalaan ${ }^{28}$.
Sparen tekniikka: monogrammin luominen ja aktivointi

Spare kirjoittaaa teoksessa The Book of Pleasure omaa maagista uskomusjärjestelmäänsä kuvatessaan: "Sinetit [sigils] ovat ajattelun monogrammeja, energian hallitsijoita". ${ }^{29}$ Spare käytti monogrammeja sekä abstrakteihin että konkreettisiin tarkoituksiin. Hän kertoo, että niiden avulla voi tehdä typeryksestä viisaan, parantaa sairaan ja saavuttaa mittavat fyysiset voimat ${ }^{30}$. Spare käytti maagista monogrammia myös osana rituaalia, jossa hän manaa hengen kahden vieraan pyynnöstä. Aloittaessaan rituaalin Spare piirtää aluksi monogrammin valkoiseen korttiin, jonka jälkeen hän lausuu loitsun tai mantran. Kun Spare manaa hengen takaisin, hän painaa piirtämänsä monogrammin otsaansa vasten ja lausuu loitsun väärin päin, jolloin henki katoaa. Spare ajatteli, että paikalle kutsuttu henki oli osa toisen vieraan alitajunnan dissosiatiivista tilaa. ${ }^{31}$ Tämä kuvaus vertautuu otollisella tavalla artikkelissa myöhemmin esitettyihin tapoihin, joilla monogrammeja on magian historiassa käytetty henkien kutsumiseen.

Sparenjärjestelmä toimii samanaikaisesti konkreettisella ja abstraktilla tasolla: 
monogrammi luodaan konkreettiseksi maagiseksi kuvioksi, mutta sen toiminta perustuu uskomusjärjestelmän abstraktilla tasolla toimiviin symboleihin $Z^{32}$ ja Kia. Teoksessa The Book of Pleasure monogrammeja sisältävän kuvan alla Spare kirjoittaa: "Kehoa kokonaisuutena, kutsun termillä Zos". ${ }^{33}$ Zos edustaa Sparen ajattelussa kehoa, mieltä ja sielua ${ }^{34}$. Kia taas määritellään teoksen johdannossa: "Absoluuttinen vapaus, joka on vapaudessaan niin voimakasta, että se muodostaa 'todellisuuden'". ${ }^{35}$ Kia ei tarkoita vapauden idean tai keinojen manifestoitumista, vaan egoa joka on vapaa vastaanottamaan Kian täydellisesti, koska pystyy pidättäytymään sitä koskevista ideoista ja uskomuksista. Magian harjoittajan on mahdollista herättää alitajunnassa latenttina ilmenevä pohjimmainen energia näitä peruselementtejä hyödyntäen. Sparen järjestelmässä magian harjoittaja luo monogrammin yhdistyen luovaan energiaan ja tahtoon, jota Zos edustaa. Tämän jälkeen monogrammi aktivoidaan yhdistymällä Kian energiaan. Kia edustaa järjestelmässä eräänlaista tyhjyyttä, jonka toiminnan alusta Zos on. ${ }^{36}$
Sparen toisiinsa kietoutuvat roolit sekä okkultistina että kuvataiteilijana ilmenevät myös hänen okkultistisen järjestelmänsä rakenteessa. Symbolit Zos ja Kia liittyvät myös luovaan työskentelyyn, sillä ne edustavat seksuaalienergian kahta polariteettia, joiden antropomorfiset symbolit ovat käsi ja silmä ${ }^{37}$. Zos symboloi fallista tahtoa ja luovaa tarvetta tehdä. Käden ja silmän yhteistyö viittaa tahtoon ja sen muuttumiseen konkreettiseksi halun ja mielikuvituksen kautta. ${ }^{38}$

Sparen maagisen monogrammin luomisen lähtökohta on magian harjoittajan tahto tai halu, jolle luodaan visuaalinen ja konkreettinen muoto. Tahto muotoilIaan lauseeksi ja se kirjoitetaan paperille. ${ }^{39}$ Spare ohjeista muotoilemaan lauseen alun aina samalla tavalla, jonka jälkeen magian harjoittaja lisää sen loppuun tavoittelemansa asian. Spare antaa esimerkin lauseesta: "Tahtoni on / saavuttaa / tiikerin voimat."40 Tämän jälkeen lauseen kirjaimista yhdistellään yksinkertainen kuvio. Spare havainnollistaa (Kuva 2), miten hän luo esimerkkilauseeseen perustuvan monogrammin, joka on helppo visualisoida mieleen. Seuraavaksi monogrammi lähe-
"This my wish to obtain the strength of a tiger." Sigi-

lized this would be:-

$$
\begin{gathered}
\text { This my wish } \\
\text { To obtain }
\end{gathered}
$$

The strength of a Tiger

Combined as one Sigil or

Kuva 2. Austin Osman Sparen monogrammeja teoksesta Jed Rasula \& Steve McCaffery (eds.), Imagining Language: An Anthology. (London: MIT Press, 2001), 369. 
tetään alitajuntaan, joka sisältää tarpeellisen voiman sen aktivoimiseen. ${ }^{41}$ Sparen ohjeistuksessa monogrammi aktivoidaan mielen tyhjänä hetkenä magian harjoittajalle itselle sopivimmalla tavalla. Hän antaa siihen useita mahdollisia keinoja, kuten mantra, kuoleman asento, naiset ja viini, tennis, mietiskely ja kävelymeditaatio. Sitä miten tila tulisi saavuttaa, ei rajata tarkasti, ja ohjeen mukaan magian harjoittaja voi päättää keinon myös itse ${ }^{42}$. Sparen mukaan monogrammin aktivointi on vaikeampaa kuin sen luominen ${ }^{43}$.

Sparen järjestelmässä alitajunta tulee maagisten merkkien käytön perinteessä yleisen henkiolentojen todellisuuden tilalle, sillä hänelle maaginen monogrammi oli tarkasti rajattu alitajunnalle suunnattu ohje ${ }^{44}$. Tässä yhteydessä on hyvä huomata, että erottelu alitajuntaan ja tietoiseen mieleen oli uusi 1900-luvun alussa. Ei voi kuitenkaan tulkita yksiulotteisesti, että Sparen järjestelmässä psykologia ja tieteellinen maailmankuva tulisivat henkiolentojen todellisuuden tilalle. Sparen symbolit Zos ja Kia ovat elimellinen osa hänen okkultistista tekniikkaansa. Alitajunta ei Sparen tekstien perusteella vaikuta tarkoittavan pelkästään psykologian piirissä käytettyä käsitettä, vaan hänen järjestelmänsä okkultistiset voimat ovat siirtyneen toimimaan myös alitajunnassa. Spare yhdistää järjestelmässään inmismielen toimintaa käsittelevää psykologista ajattelua, okkultistista ajattelua ja luovaa työskentelyä. Tämä selittää osaltaan, miksi hän ei lainannut järjestelmänsä periaatteita ja rituaaleja suoraan maagisten merkkien traditiosta vaan uudisti perinnettä.

Myöhemmin useammat tahot ovat kirjoittaneet Sparen monogrammin luomisen tekniikasta ja samalla muokanneet joitakin siihen liittyviä yksityiskohtia. Erityisesti Grantin teos Images \& Oracles of Austin Osman Spare (1975) on vaikuttanut Sparen järjestelmästä tehtyihin tulkintoihin. Grant lisää The Book of Pleasuren ohjeeseen tiikerin voimia käsittelevään esimerkkiin viitaten [Kuva 2], että kun magian harjoittaja on muotoillut lauseen paperille, toistoa tulisi välttää ja samat kirjaimet poistaa lauseesta. ${ }^{45}$ Sparen ohje on yleisempi, ja kuten kuvasta voi huomata, esimerkiksi s- ja o-kirjaimet toistuvat monogrammeissa. Populaarikulttuurissa Sparen monogrammin luomisen tekniikan teki tunnetuksi vuonna 1978 syntynyt kaaosmagian teoria, jota Peter J. Carroll käsittelee teoksessa Liber Null (1978) ja Ray Sherwin erityisesti maagisten merkkien näkökulmasta teoksessa The Book of Results (1981). Molemmissa seurataan Grantin esittämää ohjetta kirjaimien toiston välttämisestä ${ }^{46}$. Vielä uudempi teksti aiheesta on sarjakuvakäsikirjoittaja Grant Morrisonin essee "Pop Magic!" (2003), jossa ohjeistetaan tässä vaiheessa monogrammin luomista poistamaan paperille muotoillusta lauseesta toiston lisäksi myös vokaalit ${ }^{47}$.

Grant esitti myös, että maaginen kuvio tulisi unohtaa ja sen ajattelemista tietoisesti tulisi välttää, kun se aktivoidaan. Kuviota tulisi ajatella ainoastaan "maagisena aikana", mikä tarkoittaa hetkeä, jolloin magian harjoittaja on elementaalisen tai tunteellisen reaktion vallassa, esimerkiksi kokiessaan orgasmin tai kipua ja tuntiessaan mielihyvää tai ahdistusta. ${ }^{48}$ Carroll taas esitti, että monogrammi voidaan myös aktivoida polttamalla, hautaamalla tai heittämällä se mereen ${ }^{49}$. Sherwinin teos esittää laajasti hyvin eri perinteistä koostettuja tekniikoita mono- 
grammin aktivointiin ${ }^{50}$. Morrison puolestaan seuraa Grantin ajattelua ${ }^{51}$. Myöhemmät kirjoitukset Sparen maagisen kuvion luomisesta ottavat monilta osin vaikutteita Grantin yksityiskohtaisesta kommentaarista. Sparen vaikutus Grantin ajatteluun ja omiin teksteihin on tunnustettu, mutta se on jäänyt vähemmälle huomiolle, että myös Grantin tekstit ovat vaikuttaneet käsityksiin Sparen maagisesta järjestelmästä.

\section{Sparen monogrammien sijoittumi- nen maagisten karakterien perin- teeseen}

Sparen monogrammit ovat osa maagisten karakterien perinnettä, joka on peräisin antiikista. Karakterit johtuu muinaiskreikan sanasta $\chi \alpha \rho \alpha \kappa т \tilde{\eta} \rho \varepsilon \varsigma$ ja sitä on käytetty länsimaisen esoterian traditiossa nimeämään maagisia merkkejä ja symboleja ${ }^{52}$. Kreikkalaisissa lähteissä maagiset karakterit eivät yleensä muodosta luettavia sanoja, kun koptilaisissa lähteissä merkit muodostava enkelien sekä muiden pyhien olentojen nimiä53. Yksi varhaisimmista esineistä, jossa on todennetusti löydetty karaktereja, on Ateenan arkeo- logiselta Agoralta löydetty kreikkalainen kiroustaulu. Se on ajoitettu noin vuosiin 50-150 jaa. ${ }^{54}$ Kiroustauluja käytettiin antiikissa yliluonnollisten voimien manaamiseen, joiden oli tarkoitus vaikuttaa toisiin inmisiin tai eläimiin ${ }^{55}$. Maagiset merkit, joita rituaalitauluissa käytettiin, olivat useimmiten jumaluuksien tai muiden henkien nimiä tai astrologisia merkkejä. Tauluihin kirjoitettiin myös kreikaksi ja latinaksi, mutta yleensä salausmenetelmää käyttäen. Yksi salausmenetelmä oli tekstin kirjoittaminen takaperin. ${ }^{56}$

Keskiajan maagisten merkkien luokittelun tehneet Benoît Grévin ja Julien Véronèse tuovat esiin, että monogrammia voitiin käyttää samalla tavalla kuin sinettiä (sigillum), jotka suunnattiin planetaarisille enkeleille pyhän monogrammin ominaisuudessa, kuten Almandalin pentaakkeli (pentaculum de l'Almandal) ${ }^{57}$. Grévin ja Véronesè sijoittavat monogrammit seuraavalla tavalla osaksi maagisia karaktereja: (a) konventionaaliset merkit, joilla viitataan tunnistettaviin aakkosiin (latina, kreikka, heprea) (b) yksinkertaiset geometriset kuviot (kuten risti ja pentagrammi) (c) pseudoideogrammit (merkkejä, jotka näyttävät Kaukoidän kirjoitusmerkeiltä ja joita käytettiin henkilöiden, enkeleiden ja planeettojen nimistä) (d) caractères à lunettes tai astraaliset merkit (näillä viitataan pieniin geometrisiin kompositioihin, joiden lähtökohta on alun perin astrologiassa) (e) monogrammit (tunnistettavista elementeistä, kuten kirjaimista tai ristinmerkeistä muodostetut karakterit) ja (f) monimutkaiset geometriset kompositiot ${ }^{58}$.

1500-luvun alussa vaikuttanut Heinrich Cornelius Agrippa oli ensimmäinen oppinutta magiaa tutkinut henkilö, joka piti alaa filosofian osa-alueena ${ }^{59}$. Hän teki teoksessa De occulta philosophia libri III (1533, "Kolme kirjaa okkulttisesta filosofiasta") systemaattisen esityksen maagisista karaktereista, joihin hän liitti mukaan salakirjoitukset, heprealaiset kirjoitusmerkit ja monogrammit ${ }^{60}$. Agrippa antaa teoksessa ohjeen maagisen monogrammin luomiseen, jota voi hänen mukaansa käyttää useimmilla kirjoitusjärjestelmillä. Siinä liitetään yhteen latinan, kreikan tai heprean kirjaimia, joista luodaan uusi maaginen kuvio (Ks. Kuva 3). Agrippan maailmankuvassa henget ovat 
ruumiittomia, inmistä korkeampia olentoja, jotka koostuvat puhtaasta älystä. Monogrammi ohjeistetaan suuntaamaan enkelille, jolta halutaan hyveitä ja voimaa. Jos enkeli vastaa kutsuun, inminen voi nousta henkiolentojen todellisuuteen ja saavuttaa tavoittelemansa kyvyt. ${ }^{61}$

Renessanssin aikana vaikutti myös Giordano Bruno, joka harjoitti mnemoniikkaa (ars memoriae) yhdistäen järjestelmäänsä magian tekniikoita. Brunon mnemoniikka perustui maailmankuvaan, jossa maallisen todellisuuden elementtien konkreettisten ilmentymien kautta oli arkkityyppisten kuvien avulla mahdollista olla yhteydessä henkien todellisuuteen $^{62}$. Brunon muistijärjestelmä oli samalla loputtomasti muuntuva varasto kuvioita, joiden avulla pystyi sitomaan henkiolentoja ${ }^{63}$. Teoksessa De magia naturali (1589-1590, "Luonnonmagiasta") Bruno tuo esiin, että henkiolentojen kanssa ei voi kommunikoida inmisten kielillä ${ }^{64}$. Hänen mukaansa demonit ymmärtävät paremmin luonnon symbolien avulla välitettyä kommunikaatiota, sillä ne oppivat kielen sisäsyntyisesti.

Sparen on esitetty tunteneen myös tavan, jolla niin kutsutussa salomonisessa perinteessä ${ }^{65}$ ja erityisesti sen goetiaksi kutsutussa alassa käytettiin maagisia karaktereja jumalallisten ja demonisten henkien manaamiseen ${ }^{66}$. Lemegeton Clavicula Salomonis oli keskiajan lopulla ja uudella ajalla kiertänyt seremoniallisen magian manuaali, joka sisälsi demonien manaamista käsittelevän osion. Käsikirjoituksessa annetaan sinetit 72 hengelle, joiden avulla magian harjoittaja voi manata henkiä avukseen, saada niiltä erilaisia suotuisia voimia ja pyytää niitä
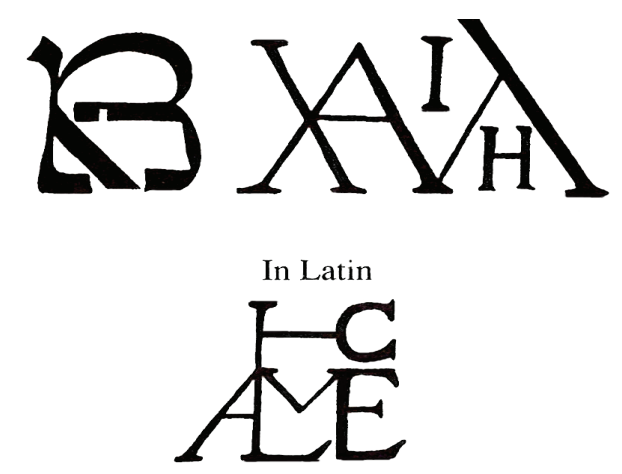

Kuva 3. Cornelius Agrippan monogrammeja teoksesta Corneilus Agrippa, Three Books of Occult Philosophy. Three Books of Occult Philosophy, (trans.) James Freake, (ed.) Donald Tyson (St. Paul: Llewellyn Publications, 1997), 562 (3.30).

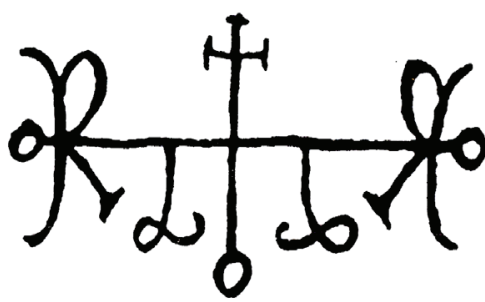

Kuva 4. Henki 35 Marchosias, teoksesta Joseph Peterson (ed.), The Lesser Key of Solomon: Detailing the Ceremonial Art of Commanding Spirits Both Good and Evil (York Beach: Weiser Books, 2001), 23.

vaikuttamaan tulevaisuuden tapahtumiin. Kuvan 4 maaginen karakteri on luotu tunnistettavista elementeistä, eli kirjaimista ja rististä, joten se sijoittuu Grévinin ja Véronesèn luokkaan monogrammit. Demoni nimeltä Marchosias ilmestyy suden muodossa, jolla on aarnikotkan siivet ja käärmeen häntä ja joka oksentaa suustaan tulta. Manaajan on kuitenkin mahdollista saada hänet muuttumaan ihmisen näköiseksi, jonka jälkeen hän vastaa kysymyksiin totuudenmukaisesti ${ }^{67}$.

Maagiset karakterit sulautuivat 1600 - ja 1700-luvuilla osaksi ruusuristiläistä symboliikkaa, joka sai alkunsa kolmesta ma- 
nifestista ${ }^{68}$. Maagisia karaktereita sisälsi liikkeen kolmas manifesti Hermeettinen romanssi eli Christian Rosenkreutzin kemialliset häät (1616), joka on allegorinen kertomus taivaan ja maan yhdistävistä häistä. Kertomus jakautuu seitsemään lukuun, joista jokainen tapahtuu yhden päivän aikana. Tekstin kirjoittaja oli Johann Valentin Andreae (1586-1654), joka osallistui myös kahden muun ruusuristiläisen manifestin kirjoittamiseen yhdessä Christoph Besoldin ja Tobias Hessen kanssa. Kertomusta on tulkittu esoterian näkökulmasta tekstinä, johon on kätketty allegorian, symboliikan ja maagisten karakterien avulla ruusuristiläisten käsityksiä alkemiasta. ${ }^{69}$ Tämän lisäksi teksti on tulkittu romaaniksi, romanssiksi, fantasiaksi ja satiiriksi ${ }^{70}$. Alkuperäisen käsikirjoituksen kuvituksena on pääasiassa maagisia karaktereja sen sijaan että se olisi sisältänyt kuvia teoksen allegorisista kohtauksista ${ }^{71}$.

Kertomuksen alussa Rosenkreutz on vaipuneena meditaatioon ja hänen luokseen ilmestyy olento, jonka tähdillä koristelluissa vaatteissa välkehtivät kaikki taivaan värit. Olennolla on myös

Kuva 5. Monas hieroglyphica teoksesta [Johann Valentin Andreae], Chymische Hochzeit Christiani Rosencreutz, Anno 1459 (Straßburg: Lazarus Zetzner 1616), 5.

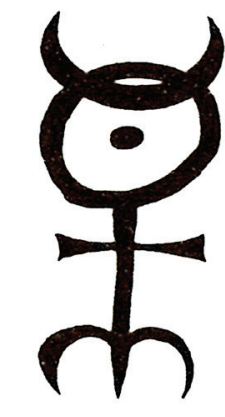

suuret ja kauniit siivet, jotka ovat täynnä silmiä ja joilla se pystyy lentämään kuin kotka. Olento laittaa Rosenkreutzin pöydälle hääkutsun, joka on sinetöity monogrammilla monas hieroglyphica (Kuva 5). ${ }^{72}$ Kyseinen monogrammi on tunnettu alkemian symboleista kirjoittaneen John Deen (1527-1608/1609) samannimisestä teoksesta Monas Hieroglyphica (1564, "Hieroglyfinen monadi"), joka käsittelee sen kerrostuneita merkityksiä. Monas Hieroglyphica koostuu erilaisista tunnistettavista elementeistä, kuten risti ja kirjaimet sekä abstrakteista geometrisista muodoista, kuten kaari, kehä, viiva

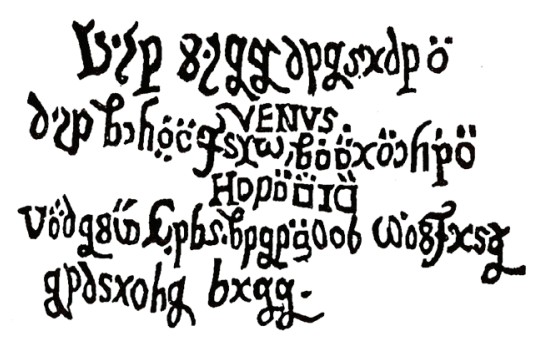

Kuva 6. Ruusuristiläisten okkulttista kirjoitusta teoksesta [Johann Valentin Andreae], Chymische Hochzeit Christiani Rosencreutz, Anno 1459 (Straßburg: Lazarus Zetzner 1616), 99.

ja piste. Tämän lisäksi se sisältää lukuisia astrologisia merkityksiä. Dee esittää, että ylhäältä alas sen osat edustavat kuuta (kuu), aurinkoa (kehä ja piste), elementtejä (risti) ja tulta (B-kirjain) ${ }^{73}$.

Tämän lisäksi Hermeettinen romanssi sisältää neljässä kohtaa kirjoitusta, joka on luotu okkulttisella eli salaisella aakkostolla (Kuva 6$)^{74}$. Kertomuksessa hovipoika kääntää kuvassa näkyvän kirjoituksen merkityksen Rosenkreutzille seuraavalla tavalla: "Kun hedelmä puustani on kokonaan sulanut, herään ja minusta tulee Kuninkaan äiti". ${ }^{75}$ Vaikka tämä tuntematon kirjoitus käännetään teoksessa, se ei 
edusta mitään tunnettua kirjoitusjärjestelmää eikä sitä voi lukea luonnollisten kielten tavoin. IIman yhteyttä tarinaan sitä olisi mahdoton ymmärtää, joten käännöstä tulee pitää imaginäärisenä.

Hermetic Order of the Golden Dawn on Lontoossa vuonna 1888 perustettu ruusuristiläisten ajattelusta ja vapaamuurareilta vaikutteita ottanut järjestö. Sen perustajajäsenet olivat William Robert Woodman (1828-1891), William Wynn Westcott
(1848-1925) ja Samuel Liddell Mathers (1854-1918). ${ }^{76}$ Järjestössä käytettiin maagisten karakterien luomiseen erityistä ruusuristin muotoista kuviota, jonka terälehdille heprean tai latinan aakkoset on sijoitettu kehämäisesti (Kuva 7). Maaginen karakteri luodaan kuvion avulla niin, että ruusun terälehtien päälle laitetaan läpinäkyvä paperi, jonka päälle merkki piirretään. Kuvio aloitetaan kirjaimesta, jolla hengen nimi alkaa ja siitä läh-

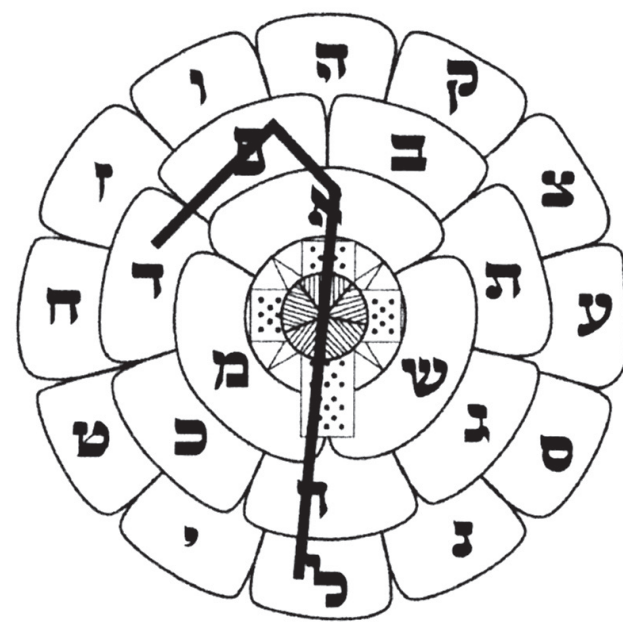

Hebrew

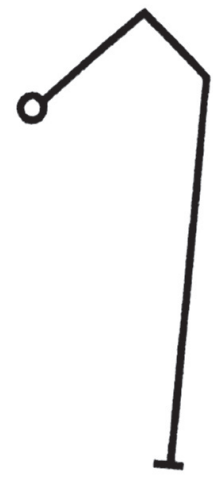

Raphiel - correct
Kuva 7. Hermetic Order of the Golden Dawnin käyttämä ruusuristi, teoksesta Mark Jackson, Sigils, Ciphers and Scripts: History and Graphic Function of Magick Symbols (Glastonbury: Green Magick, 2013), 49. tien piirretään nimen kirjaimet aina viiva kerrallaan niin että lopputulokseksi muodostuu yhtenäinen kuvio. Kun maaginen karakteri on luotu, sitä voidaan kääntää ja siitä voidaan tehdä peilikuva. ${ }^{77}$ Hermetic Order of the Golden Dawnin piirissä tätä maagista merkkiä kutsuttiin hengen karakteriksi, jonka uskottiin edustavan kutsuttavan entiteetin "sielun kuvaa", jonka avulla siihen pystyi ottamaan yhteyden ${ }^{78}$.

\section{Aseemista okkultismia}

André Bernand tuo esiin, että käsittämättömiä (incompréhensible) merkkejä tai kirjaimia esiintyy usein antiikin maagisten karakterien yhteydessä79. Antiikin kiroustaulujen yhteydessä oli yleistä useiden erilaisten salaustapojen käyttö, jotka vaikeuttivat maagisten merkkien suoraa ymmärtämistä ${ }^{80}$. Antiikin teurgiassa ${ }^{81}$ käytetyt karakterit, joilla oli okkulttinen merkitys, olivat puolestaan usein sellaisia, ettei niitä voinut lukea ääneen eivätkä ne muistuttaneet mitään tunnettua aakkostoa. Niitä käytettiin kirjoitetussa muodossa sen takia, että niiden viittauskohde oli yleensä vakiintunut ja kirjoitettu merkki kesti historiaa paremmin kuin suullinen ilmaisu. ${ }^{82}$ Grévin ja Véronèse tuovat esiin keskiai- 
kaisten maagisten merkkien luokittelussa pseudoideogrammit ja monogrammit, joita ei voinut lukea ääneen ${ }^{83}$. Agrippa liitti maagisten karakterien luokkaan salakirjoitukset, joiden tavoitteena on lukemisen vaikeuttaminen niin, ettei tekstiä ymmärrä kuin sen koodin tunteva henkilö. Tämän lisäksi hän liitti niihin monogrammit, jotka eivät muistuttaneet tunnettuja kirjoitusjärjestelmiä, koska niillä oli tarkoitus kommunikoida jumalallisten olentojen kanssa ${ }^{84}$. Ruusuristiläisten kolmannessa manifestissa puolestaan on esoteerista kirjoitusta ${ }^{85}$. Vaikka kirjoitus käännetäänkin teoksessa, se ei edusta mitään tunnettua kirjoitusjärjestelmää eikä sitä voi lukea luonnollisten kielten tavoin. Ilman yhteyttä tarinaan kirjoitusta olisi mahdoton ymmärtää, joten tulkitsen sen aseemiseksi kirjoitukseksi. Esiin nousseista karaktereista selkeimmin aseemisia ovat pseudoideogrammit, ruusuristiläisten okkulttinen kirjoitus ja osa Sparen monogrammeista. Tämä johtuu siitä, että muistuttavat kirjoitusta, mutta ne eivät itsessään välitä katsojalleen luonnollisille kielille tyypillisiä merkityksiä tai muita konventionaalisia merkityksiä. Niitä ei voi myöskään lukea ääneen.
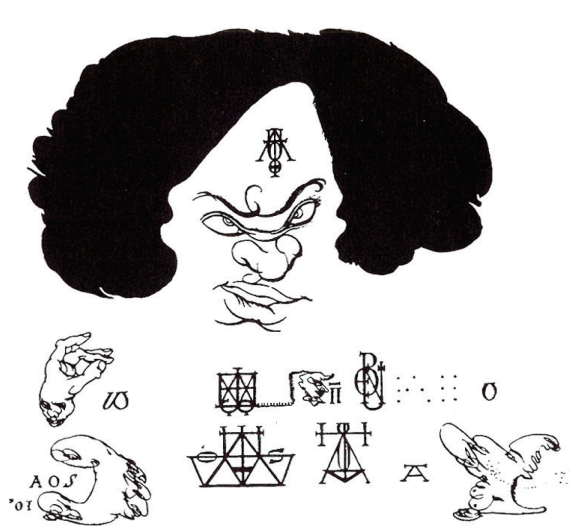

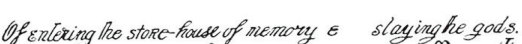

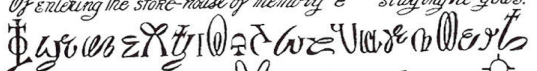
Mas I emerge from bie host ancient one: nor shall le fefered my hand.

THE THUMB CONCENTRATION.

$$
\text { Sigits: Belief with protection }
$$

Kuva 8. Austin Osman Spare, The Thumb Concentration, teoksesta Jed Rasula \& Steve McCaffery (eds.), Imagining Language: An Anthology. (London: MIT Press, 2001), 369.

Tarkastelen seuraavaksi Sparen mustetyötä "The Thumb Concentration" tarkemmin aseemisuuden näkökulmasta (Kuva 8). Monogrammien aseemisuus vaihtelee riippuen siitä, onko niissä selkeästi tunnistettavissa yksittäisiä kirjaimia. Selkeästi aseemisilta näyttävät kuvan keskellä sijaitsevassa neljän monogrammin ryhmässä ylhäällä ja vasemmalla sijaitseva monogrammi sekä alhaalla ja oikealla sijaitseva monogrammi. Samoin tämän ryhmän ulkopuolella miehen otsaan sijoittuva monogrammi näyttää aseemiselta. Ylhäällä oikealla sijaitseva monogrammi sisältää kokonaiset tunnistettavat kirjaimet $R, O, E$ ja $U$, jolloin se sisältää kirjaimiin kytkeytyvien foneemien kautta konventionaalisia merkityksiä. Myös alhaalle vasemmalle sijoittuva monogrammi sisältää selvästi kokonaiset kirjaimet $S$ ja O. Analyysi osoittaakin, että Sparen tavoite luoda monogrammeista sellaisia, että ne sisältäisivät mahdollisimman vähän yhteyksiä magian harjoittajan lauseeksi muotoilemaan tahtoon, ei aina toteudu. Toisaalta monogrammeja on mahdotonta lukea ääneen, vaikka niissä erottuisikin yksittäisiä kirjaimia.

\section{Lopuksi}

Maagisia karaktereja on tehty antiikista alkaen muilla kuin luonnollisilla kielillä sen vuoksi, että niillä on kutsuttu henkiolentoja, joiden ei ole ajateltu ymmärtävän inhimil- 
lisiä kieliä. Sparen monogrammista pyritään tekemään aseeminen siksi, että hän uskoi alitajunnalle suunnatun kommunikaation tapahtuvan symboliikan avulla, joka on jokaiselle magian harjoittajalle yksilöllistä. Sparen järjestelmässä alitajunnan kanssa ei voi kommunikoida tietoisen mielen käyttämällä kielellä tai merkkijärjestelmällä, vaan magian harjoittajan pitää luoda kommunikaatiota varten visuaalisesti yksilöllisiä maagisia merkkejä. Maagisten karakterien tarkastelu aseemisen kirjoituksen näkökulmasta nosti esiin useita tapauksia, joissa maagisten merkkien luettavuutta vaikeutetaan erilaisin tekniikoin. Tämä perinne auttaa tarkentamaan käsitystä aseemisesta kirjoituksesta, jonka yhteyksiä länsimaiseen maagisten karakterien traditioon olisi myös mielekästä tutkia lisää.

\section{Viitteet}

1 Maagisten merkkien perinteessä monogrammi tarkoittaa tunnistettavista elementeistä, kuten kirjaimista muodostettuja kuvioita. Benoît Grévin \& Julien Véronèse, "Les 'caractères' magiques au Moyen Âge (XIle-XIVe siècle)", Bibliothèque de I'École des chartes 2004: 367.

2 Benedek Láng luokittelee keskiajan oppineen magian osa-alueiksi luonnonmagian, kuvamagian, rituaalimagian ja ennustamisen. Toisinaan myös alkemia nähdään magian osa-alueena, mutta tutkimuksessa sen on todettu muodostavan oman kirjallisen perinteensä. Benedek Láng, Unlocked books. Manuscripts of learned magic in the medieval libraries of Central Europe (University Park, PA: Pennsylvania State University, 2008), 36-43.

3 Láng huomioi, että kuvamagia on keskiajalla liittynyt usein luonnonmagiaan ja astrologiaan, mutta sitä on käytetty myös enkeleiden ja demonien manaamiseen, jolloin se sisältää yhteisiä piirteitä rituaalimagian kanssa. Láng, Unlocked books, 36-37. 4 Sanoja okkultismi ja okkulttinen käytetään usein samassa merkityksessä, mutta todellisuudessa ne viittaavat eri ajanjaksoon länsimaisen esoterian perinteessä. Sanan okkultismi käyttö alkaa 1800-luvulta ja sanaa okkulttinen käytettiin jo antiikissa. Okkultismi (occultism) ja okkulttinen (occult) ovat molemmat peräisin latinan adjektiivista occultus 'piilotettu, salainen'. Wouter J. Hanegraaff, "Occult/Occultism". Teoksessa Dictionary of Gnosis \& Western Esotericism II, (eds.) Wouter J. Hanegraaf, Antoine Faivre, Roelof van den Broek, Jean-Pierre Brach (Leiden, Boston: Brill, 2005), 884-889.

5 Kaaosmagian käsitteen loivat Peter J. Carroll (s. 1953) ja Ray Sherwin (s. 1952), jotka ottivat vaikutteita Sparen teoksista. He alkoivat luoda järjestelmän pohjalta omaa magian teoriaa, jota he kehittivät vuonna 1978 perustamassaan järjestössä Illuminates of Thanateros (IOT). Kaaosmagian harjoittaja käyttää vapaasti eri uskomusjärjestelmiä ja länsimaisen magian perinteen tekniikoita tavoittelemansa tuloksen saavuttamiseen. Osa kaaosmagian harjoittajista ammentaa myös fantasian scifin ja muun populaarikulttuurin mytologioista ja symboleista. George Chryssides, Historical Dictionary of New Religious Movements (Scarecrow Press, 2011), 91; Peter Clarke (ed.), Encyclopedia of New Religious Movements (Florence: Routledge, 2004), 105.

6 Riikka Ala-Hakula, "Kaiverrettu taival-Aseemiset rivit", Avain 2/2016, 59.

7 Luonnollinen kieli tarkoittaa ihmisryhmän äidinkielenään käyttämää kieltä, joka on luonnollisen kehityksen tulos, kuten suomi tai englanti. Ihminen käyttää luonnollista kieltä sekä kommunikaation että ympäröivän maailman verbaaliseen hahmottamiseen. Fred Karlsson, Yleinen kielitiede (Helsinki:

Yliopistopaino, 2004), 1-2.

8 Ks. Riikka Ala-Hakula, TEKSTITAIDE: aseeminen kirjoitus Henri Michaux'n runokokoelmassa

Mouvements, Bernard Réquichot'n kirjeissä Ecritures illisibles ja Luigi Serafinin ensyklopediassa Codex Seraphinianus, Pro gradu -tutkielma (Jyväskylä:

Jyväskylän yliopisto, Taiteiden ja kulttuurin

tutkimuksen laitos, 2014).

9 Nina Parish, "Between Text and Image, East and West: Henri Michaux's Signs and Christian

Dotremont's 'Logogrammes'”, RiLUnE, 8, 67-80.

10 Ks. Henri Michaux: Mouvements (1951), Par la voie des rythmes (1974), Saisir (1979), Par les traits (1984) ja Christian Dotremont Logogrammes (2011). 11 Austin O. Spare, The Book of Pleasure. Teoksessa The Writings of Austin Osman Spare: Automatic Drawings, Anathema of Zos, The Book of Pleasure, and The Focus of Life (Sioux Falls: NuVision

Publications, 2007), 92.

12 Kenneth Grant, Images \& Oracles of Austin Osman Spare (London: PCM Fulgur, 2003), 11.

13 Phil Baker, Austin Osman Spare: The Life and Legend of London's Lost Artist (London: Strange Attractor Press, 2012), 23-30; Grant, Images \& Oracles, 11.

14 Baker, Austin Osman Spare, 18.

15 Mt., 129.

16 Mt., 31.

17 "Austin Osman Spare: The man art history left behind - in pictures", Guardian 6.5.2011, luettu 22.5.2018, https://www.theguardian.com/ artanddesign/gallery/2011/may/06/austin-osmanspare-art-painting

18 Grant, Images \& Oracles, 18-21.

19 Gavin Semple, "A Few Leaves from the Devil's Picture Book", teoksessa Two Tracts on Cartomancy (London: Fulgur, 1997), 21; Baker, Austin Osman Spare, 18-20. 
20 Spare, The Book of Pleasure, 93.

21 Sparen järjestelmän symbolia Kia kutsutaan

myös termillä Neither-Neither ("Ei-eikä"), jota ei pysty

käsitteellistämään, mutta johon on mahdollista ottaa yhteys maagisilla merkeillä. Böhmen ajattelu sisältää saman tyyppisen käsitteen Ungrund, jota kutsutaan termeillä loputon ei-mikään (ein ewig Nichts) ja ikuinen silmä vailla olemusta (ein ewigen Auge ohne Wesen). Böhmen ajattelussa ruumis on magian harjoittamisen työkalu, johon vaikutetaan pyhällä kielellä ja jossa pyhä ruumiillistuu mielikuvituksen toiminnan avulla. Joshua Levi lan Gentzke,

"Imagining the Image of God: Corporeal Envisioning in the Theosophy of Jacob Böhme". Teoksessa Lux in Tenebris: The Visual and the Symbolic in Western Esotericism, (ed.) Peter J. Forshaw, (Boston: Brill, 2017), 114.

22 Roland Edighoffer, "Rosicrucianism I: First half of the 17th Century". Teoksessa Dictionary of Gnosis \& Western Esotericism II, (eds.) Wouter J. Hanegraaf, Antoine Faivre, Roelof van den Broek, Jean-Pierre Brach (Leiden, Boston: Brill, 2005), 1013.

23 Hugh B. Urban, Magia Sexualis: Sex, Magic, and Liberation in Modern Western Esotericism (Berkeley,

Calif: University of California Press, 2006), 16 24 Mark Jackson, Sigils, Ciphers and Scripts: History and Graphic Function of Magick Symbols (Glastonbury: Green Magick, 2013), 48-49.

25 Grant, Images \& Oracles, 7.

26 Marco Pasi, "Aleister Crowley". Teoksessa Dictionary of Gnosis \& Western Esotericism I, (eds.) Wouter J. Hanegraaf, Antoine Faivre, Roelof van den Broek, Jean-Pierre Brach (Leiden, Boston: Brill, 2005), 281-283.

27 Pasi, "Aleister Crowley", 286

28 Wallace tulkitsee, että Kia on syntynyt suhteessa kabbalan symboliin Chiah. Kabbalan piirissä sielua kuvastaa kolme elementtiä, jotka ovat Nefesh (elämä), Ruah (henki) ja Chiah (absoluutti). Chiah edustaa egon tyhjentymistä absoluuttiin. William Wallace, The Early Work of Austin Osman Spare (Stroud, UK: Catalpa
Press, 1987), 13.

29 "Sigils are monograms of thought, for the

government of energy"; Spare, The Book of Pleasure, 91.

30 Spare, The Book of Pleasure, 92.

31 Grant, Images \& Oracles, 21-22.

32 Kenneth Grant avaa Sparen teoksissa vähäiselle määrittelylle jäävän symbolin Zos merkitystä teoksessa Images \& Oracles of Austin Osman

Spare, joka perustuu Grantin mukaan pitkälti Sparen julkaisematta jääneeseen käsikirjoitukseen The Book of the Living Word of Zos.

33 "The body considered as a whole, I call

Zos"; Spare, The Book of Pleasure (Self-Love):

The Psychology of Ecstasy, 1st edition (London: Jerusalem Press Ltd, 2011), 45.

34 Grant, Images \& Oracles, 8.

35 "Kia: The absolute freedom which being free is mighty enough to be 'reality' and free at any time"; Austin O. Spare, The Book of Pleasure, 61.

36 Grant, Images \& Oracles, 8.

$37 \mathrm{Mts}$.

38 Mt., 37.

39 Spare, The Book of Pleasure, 90-91.

40 "This my wish / To obtain / The Strength of a

Tiger", Spare, The Book of Pleasure, 92.

41 Spare, The Book of Pleasure, 92.

42 Mts

43 Mts.

44 Lynne Hume \& Nevill Drury, The Varieties of Magical Experience: Indigenous, Medieval, and

Modern Magic (Santa Barbara, California: Praeger 2013), 193

45 Grant, Images \& Oracles, 55.

46 Peter J. Carroll, Liber Null \& Psychonaut: An Introduction to Chaos Magic (York Beach, Maine: Weiser Books, 1987), 20-22; Ray Sherwin, The Book of Results (Morrisville: Lulu Enterprises, 2005), 16-22.

47 Grant Morrison, 'POP MAGIC!' Book of Lies: The Disinformation Guide to Magick and the Occult, (ed.)
Richard Metzger (San Francisco: The Disinformation Company, 2014), 19

48 Grant, Images \& Oracles, 56

49 Carroll, Liber Null \& Psychonaut, 22.

50 Sherwin, The Book of Results, 16-22.

51 Morrison, 'POP MAGIC!', 19-21.

52 Kirsten Dzwiza, "Insight into the transmission of ancient magical signs - Three textual artefacts from Pergamon", International Journal of Research on Ancient Magic and Astrology, vol. 2015 (2017): 32-33.

53 Dzwiza, "Insight into the transmission of ancient magical signs", 33

54 Dzwiza, "Insight into the transmission of ancient magical signs", 32.

55 John Gager, Curse Tablets and Binding Spells from the Ancient World (New York: Oxford University Press, 1992), 3.

$56 \mathrm{Mt}, 5$.

57 Grévin \& Véronèse, "Les 'caractères' magiques au Moyen Âge", 367

58 Grévin \& Véronèse, "Les 'caractères' magiques au Moyen Âge", 364-67

59 Michaela Valentine, "Cornelius Agrippa".

Teoksessa Dictionary of Gnosis \& Western

Esotericism, (EDS.) Wouter J. Hanegraaf, Antoine Faivre, Roelof van den Broek, Jean-Pierre Brach (Leiden, Boston: Brill, 2005), 4-8.

60 Lauri Ockenström, "Magia ja taide keskiajalta ja uuden ajan alkuun - oppinut magia ja eurooppalainen kuvamaailma 1100-1600 magian tutkimusperinteen muutosten valossa", Tahiti, 2/2015, luettu 15.5.2018, http://tahiti.fi/02-2015/tieteelliset-artikkelit/ magia-ja-taide-keskiajalta-ja-uuden-ajan-alkuunoppinut-magia-ja-eurooppalainen-kuvamaailma$1100 \%$ E2\%80\%931600-magian-tutkimusperinteen muntosten-valossal.

$61 \mathrm{H}$. Cornelius Agrippa, Three Books of Occult Philosophy, (trans.) James Freake, (ed.) Donald Tyson (St. Paul: Llewellyn Publications, 1997), 562 (3.30). 
62 Frances A. Yeates, Giordano Bruno and the Hermetic Tradition (Chicago: The University of Chicago Press, 1978), 199.

63 Manuel Mertens, Magic and Memory in Giordiano Bruno: The Art of a Heroic Spirit (Leiden, Boston: Brill, 2018), 25, 145 .

64 Mt. 75.

65 Salomonilainen perinne viittaa tekstikorpukseen, jonka magian manuaalit on laitettu viisaan Salomon nimiin. Nimi ei viittaa oikeaan historialliseen

henkilöön. Láng, Unlocked books, 29.

66 Semple, "A Few Leaves from the Devil's Picture Book", 21

67 Joseph Peterson (ed.), The Lesser Key of Solomon: Detailing the Ceremonial Art of Commanding Spirits Both Good and Evil (York Beach: Weiser Books, 2001), 23.

68 Allgemeine und General Reformation der ganzen weiten Welt (1614), Fama Fraternitatis, Deß Löblichen Ordens des Rosenkreutzes, an alle Gelehrte und Häupter Europae geschrieben (1614) ja Auch Chymische Hochzeit Christiani Rosencreutz Anno 1459 (1616)

69 Edighoffer, "Rosicrucianism I: First half of the 17th Century", 1009

70 Mt., 1012-1013.

71 Thomas Willard, "Dreams and Symbols in The Chemical Wedding". Teoksessa Lux in Tenebris: The Visual and the Symbolic in Western Esotericism, (eds.) Peter J. Forshaw, Series (Boston: Brill, 2017), 8, 139-140

72 [Johann Valentin Andreae], Chymische Hochzeit Christiani Rosencreutz, Anno 1459 (Straßburg: Lazarus Zetzner 1616), 3-5. Saatavilla: http:!!! www.deutschestextarchiv.de/book/view/valentin hochzeit $1616 ? \mathrm{p}=9$.

73 John Dee, The Hieroglyphic Monad, (trans.) J. W. Hamilton-Jones teoksesta Monas Hieroglyphica (1564) (Boston, MA/York Beach: Weiser Books, 2000), 11.

74 [Andreae], Chymische Hochzeit Christiani
Rosencreutz, 74, 97, 99, 118.

75 Christian Rosenkreutz [Johann Valentin Andreae], Hermeettinen romanssi, eli, Christian Rosenkreutz'in Kemialliset häät anno 1459, suom. Visa Kaliva (Helsinki: Kustannus Visa Kaliva, 1995), 76.

76 Robert A Gilbert, "Hermetic Order of the Golden Dawn". Teoksessa Dictionary of Gnosis \& Western Esotericism I, (eds.) Wouter J. Hanegraaf, Antoine Faivre, Roelof van den Broek, Jean-Pierre Brach (Leiden, Boston: Brill, 2005), 544-545.

77 Jackson, Sigils, Ciphers and Scripts, 48-49. 78 Mt, 48.

79 André Bernand, Sorciers grecs (Paris: Fayard,

1991), 23.

80 Gager, Curse Tablets And Binding Spells From The Ancient World, 10.

81 Teurgia ( $\theta \varepsilon$ coupyía) tarkoitti antiikin

uusplatonismissa maagisten rituaalien yhdistämistä eettisiin ja älyllisiin harjoitteisiin. Toiminnan tavoitteena oli ottaa yhteys jumalalliseen ja tulla osaksi sitä. Termin ensimmäinen vahvistettu esiintyminen on tekstifragmentista Kaldean oraakkelit, joka on ajoitettu vuosille 100-150 jaa. Crystal Addey, Divination and Theurgy in Neoplatonism: Oracles of the Gods (Farnham: Routledge, 2014), 3. ProQuest Ebook Central, http:///ebookcentral.proquest.com/lib/ jyvaskyla-ebooks/detail action?doclD $=1774176$.

82 Grévin \& Véronèse, "Les 'caractères' magiques au Moyen Âge", 314

83 Grévin \& Véronèse, "Les 'caractères' magiques au Moyen Âge ", 366, 367.

84 Ockenström, "Magia ja taide keskiajalta ja

uuden ajan alkuun"; Agrippa, Three Books of Occult Philosophy, 560-563 (3.30).

85 [Andreae], Chymische Hochzeit Christiani Rosencreutz, 74, 97, 99, 118 .
FM Riikka Ala-Hakula toimii kirjallisuuden väitöskirjatutkijana Jyväskylän yliopistossa. Hän kysyy tutkimuksessaan: Miten aseemisen kirjoituksen käsite määritellään, miten lajia voi tulkita ja millaiset teokset kuuluvat sen traditioon?

Tämän lisäksi hän suomentaa ranskalaista kirjallisuutta ja filosofiaa.

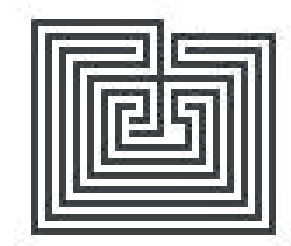

